\title{
Sand stabilization effect of feldspathic sandstone during the fallow period in Mu Us Sandy Land
}

\author{
HAN Jichang ${ }^{1,2}$, 'LIU Yansui ${ }^{2,3}$, ZHANG Yang ${ }^{1,2}$ \\ 1. Shaanxi Provincial Land Engineering Construction Group Co. Ltd., Xi'an 710075, China; \\ 2. Key Laboratory of Degraded and Unused Land Consolidation Engineering, the Ministry of Land and Re- \\ sources of China, Xi'an 710075, China; \\ 3. Institute of Geographic Sciences and Natural Resources Research, CAS, Beijing 100101, China
}

\begin{abstract}
Depended on the analysis of ground snow situation, soil moisture loss speed and soil structure after planting crops of Mu Us Sandy Land remedied with feldspathic sandstone in the fallow period, it is concluded that feldspathic sandstone mixed with sand improved the sand stabilization in the governance of Mu Us Sandy Land in the fallow period. The sandy land remedied with feldspathic sandstone had big snow coverage, $25 \%-75 \%$ higher than normal sand; soil moisture losses slowed down, and moisture content rose by over 3 times; soil structure had been improved, and water stable aggregate content increased by $6.52 \%-18.04 \%$; survival rate of protection forest increased to $85 \%$; and ground flatness is less than $1 \%$. The above conditions weakened sand rising conditions of Mu Us Sandy Land in the fallow period and formed two protective layers of snow cover and soil frozen layer under cold weather so as to prevent against wind erosion.
\end{abstract}

Keywords: feldspathic sandstone; sand stabilization; Mu Us Sandy Land; desertification; land consolidation

\section{Introduction}

$\mathrm{Mu}$ Us Sandy Land is a depression located at southeastern Ordos Plateau and north of northern Shaanxi Loess Plateau; it is one of China's four major sandy land (Han et al., 2012). Due to the long war damage in history, sharp population fluctuations, unreasonable land reclamation and overgrazing, serious grassland degradation (Liu et al., 2010), land desertification and low productivity have been caused in the Mu Us region (Kong, 1996). Serious land use issues, especially desertification and frequent sandstorm disasters not only destroyed the local ecological environment, deteriorated the natural environment, but also seriously affected the region's economic and social development, people's livelihood and production (Liu et al., 2014).

Though the research on desertification prevention and remediation has greatly progressed at present, the situation of "local governance and overall deterioration" still continues. The

Received: 2014-03-20 Accepted: 2014-08-20

Foundation: The public welfare scientific research of Ministry of Land and Resources, No.201411008

Author: Han Jichang (1966-), Professor, specialized in land engineering, land economy, and allocation of land and water resources.

*Corresponding author: Liu Yansui (1965-), PhD and Professor, E-mail: liuys@igsnrr.ac.cn 
existing sand stabilization techniques mainly include engineering (or physical, mechanical) sand stabilization, biological sand stabilization, chemical sand stabilization and comprehensive sand stabilization (Han and Zhang, 2014). Engineering sand stabilization measures mainly use materials such as wood, grass, tree branches, pebbles to set obstacles on sand surface, and use grass square, nylon mesh, concrete slab, etc., to control flowing direction, speed and structure of windblown sand, change surface roughness, and realize wind prevention and sand stabilization. Its main features are efficient but with high cost, poor compatibility with biological environment and great implementation difficulty. Biological sand stabilization makes full use of the limited water and nutrients in the sand belt to plant trees, grass or shrubs to restore the vegetation, increasing roughness and governing the desert, it can properly protect ecological environment, but the bad climatic and hydrological conditions of desert or sand caused low plant survival rate and poor sand stabilization effect, unable to ensure long-term ecological benefits and rural sustainable development (Jiang et al., 2008; Liu et al., 2013). Chemical sand stabilization sprays or scatters dry chemical material on the sand surface to form sand solidification layer, thus avoiding the direct impact of air flow on sand surface, but generally, sand stabilization cycle is short, it is difficult to be applied and implemented in a large area. As far as large-area governance, the present prevention and remediation means have limitations, modern sand prevention engineering requires efficient, cheap, rapid, convenient and environment-harmonious sand stabilization technology. To sum up the features of the above several measures, adopting good points and avoiding shortcomings, developing comprehensive sand stabilization technology or discovering one multifunctional sand stabilization material to play a role in wind prevention and sand stabilization and enable the land to generate huge economic benefits will be of great significance for the governance of Mu Us Sandy Land.

\section{Study area and methodology}

\subsection{Study area}

Mu Us Sandy Land is in semiarid and arid climate area, belonging to inland plateau, far away from the Pacific, blocked by mountains, preventing the moist air mass above the Pacific from reaching the place, and moist air above southwestern Indian Ocean is also isolated by the Himalayas. In periphery and interior of Mu Us Sandy Land there is not any mountain land or forest with high precipitation as perennial supply of water source, it is only supplied by direct infiltration of $250-300 \mathrm{~mm}$ precipitation and beam land infiltration at side direction of catchment area, the supply is limited, belonging to typical temperate continental climate, with annual mean temperature $6.0-8.5^{\circ} \mathrm{C}$, annual mean gale weather $10-40 \mathrm{~d}$, and maximum $95 \mathrm{~d}$. Gale duration of $1 \mathrm{~d}$ in Mu Us Sandy Land accounts for $60 \%-70 \%$, duration of 2-3 d about $20 \%-30 \%$, and $4-6 \mathrm{~d}$ about $5 \%$, annual mean sandstorms $11-29 \mathrm{~d}$, belonging to ecologically fragile agriculture-pasture ecotone. Annual prevailing windy season of $\mathrm{Mu}$ Us Sandy Land is from October to next May, being exactly the time of fallow period of crop cultivation in Mu Us Sandy Land. Feldspathic sandstone covers an area of $16,700 \mathrm{~km}^{2}$ in the sandy land. Feldspathic sandstone alternated with sand in Mu Us Sandy Land has low diagenetic potential and structural strength. It is also highly subject to weathering and rapidly expands when it comes into contact with water, resulting in severe soil erosion (Ye et al., 
2006; Wang et al., 2007).

The study area is located in Yuyang District $\left(108^{\circ} 58^{\prime}-110^{\circ} 24^{\prime} \mathrm{E}, 37^{\circ} 49^{\prime}-38^{\circ} 58^{\prime} \mathrm{N}\right)$ of Yulin City in south of $\mathrm{Mu}$ Us Sandy Land and windblown sand grass land area, belonging to agriculture-pasture ecotone, having superior natural conditions compared with other regions of $\mathrm{Mu}$ Us Sandy Land, but wind erosion desertification and water loss and soil erosion were serious due to man-made sabotage.

Annual prevailing windy season of $\mathrm{Mu}$ Us Sandy Land is from October to the next May, when is exactly the time of fallow period of crop cultivation in Mu Us Sandy Land. The crop harvest reduces the surface vegetation cover on the one hand, on the other hand, causes the disturbance of land to a certain extent, thus creating conditions for the movement of sandstorm. Feldspathic sandstone covers an area of $16,700 \mathrm{~km}^{2}$ in the sandy land. Feldspathic sandstone alternated with sand has low diagenetic potential and structural strength. It is also highly subject to weathering and rapidly expands when it comes into contact with water, resulting in severe soil erosion (Wang et al., 2007).

The existing researches show that, after mixing feldspathic sandstone with sand into soil in Mu Us Sandy Land, the soil's physical character can be improved, and moisture content of topsoil will be significantly increased. The Mu Us Sandy Land can play a role of natural water-retaining agent, providing a foundation for plant growth (Han et al., 2012; Yan et al., 2013). The snow covered on the surface of sand in the fallow period is regarded as a protective casing retarding windblown erosion, which has sand stabilization effect. After sand snow is melted, the exposed drift sand will generate sandstorm via wind effect, causing significant wind erosion phenomenon. It is discovered from the research of the sand of feldspathic sandstone settlement area and the original landform sand survey that, after snowfall, snow melting speed of remedied sand in this region is slower than that of the original landform sand. This paper is based on placement test and sampling analysis in test area to research the remedied land snow melting differences, reveal the formation of protective casing under wind erosion and influence mechanism of snow melting speed, and combines water retaining property and stability analysis of mixing feldspathic sandstone with sand into soil to discuss and research the sand consolidation effect of feldspathic sandstone in $\mathrm{Mu}$ Us Sandy Land.

\subsection{Research method}

\subsubsection{Survey research of snow melting}

This paper respectively surveyed remedied land covered with feldspathic sandstone and snow melting situation of original sand landform's sunny slope, shady slope and flat ground and underlying surface covered with snow. It selected slope aspect, gradient, elevation and other regions with similar terrain conditions for survey. During survey, six typical points in the study area were selected to measure snow thickness with plum blossom method, and average values were taken. Gradient of remedied land is very small, in order to get similar gradient and slope aspect for comparison, microtopography with mechanical ploughing was selected for survey. Specific terrain conditions at survey sites are shown in Table 1.

2.2.2 Method of water retaining property of soil mixed with feldspathic sandstone and sand

In the $70 \times 70 \times 50($ length $\times$ width $\times$ height $)$ osmotic vessel, the migration process of moisture of 
Table 1 Overview of the surveyed regions

\begin{tabular}{clccc}
\hline No. & \multicolumn{1}{c}{ Landform type } & Slope aspect & Gradient $\left(^{\circ}\right)$ & Elevation $(\mathrm{m})$ \\
\hline ZL-1 & After covered with feldspathic sandstone & Sunny slope & 17.3 & 1259 \\
ZL-2 & After covered with feldspathic sandstone & Shady slope & 14.7 & 1259 \\
ZL-3 & After covered with feldspathic sandstone & - & 0 & 1259 \\
YS-1 & Original landform & Sunny slope & 18.0 & 1257 \\
YS-2 & Original landform & Shady slope & 13.9 & 1257 \\
YS-3 & Original landform & - & 0 & 1257 \\
\hline
\end{tabular}

mixture of feldspathic sandstone and sand was simulated. The specific procedure is to fill in sand at 30-50 cm depth, fill in mixed sample of feldspathic sandstone and sand (diameter within $2-3 \mathrm{~cm}$ ) with a ratio of 1:2 at $0-30 \mathrm{~cm}$, connect lower part of vessel with ground, and simulate the mixing state of feldspathic sandstone and sand in the fallow period of land. Water was filled in the vessel containing mixture until the water oozes from lower part; 0-30 $\mathrm{cm}$ mixed sample of feldspathic sandstone and sand was collected respectively at $6 \mathrm{~h}, 18 \mathrm{~h}$, 30 h, 42 h, 54 h, 102 h, 294 h, 318 h and 342 h after watering, and feldspathic sandstone rock mass was stripped out of the mixture, respectively to measure the moisture content of mixture of feldspathic sandstone and sand and feldspathic sandstone rock mass. In the meantime, only sand in another vessel was filled for comparison.

2.2.3 Method for stabilizing soil mixed with feldspathic sandstone and sand

Feldspathic sandstone and sand should be mixed into soil according to ratios of 1:1, 1:2 and 1:5. We take total load as contrast, measure composite soil aggregate before and after utilization, select the sampling regions with the same condition of site $(5 \mathrm{~m} \times 5 \mathrm{~m})$ for implementation, take samples with diagonal method in the region for three times and take the average value. The test method is the Savinov' method.

\section{Results and analysis}

\subsection{Analysis of snow melting phenomenon}

It snowed in Yuyang District of Yulin City on November 26, 2011, and snow thickness was $12 \mathrm{~cm}$. After snowfall, snow melting situation survey (Table 2) was respectively performed

Table 2 Snow cover investigation list

\begin{tabular}{lcccccc}
\hline \multicolumn{1}{c}{ No. } & ZL-1 & ZL-2 & ZL-3 & YS-1 & YS-2 & YS-3 \\
\hline Survey time & 7.6 & 11.4 & 9.0 & 5.9 & 10.6 & 8.1 \\
\hline Snow thickness (cm) & 95 & 99 & 98 & 85 & 95 & 90 \\
Snow coverage (\%) & 0 & 0 & 0 & 1.5 & 1.6 & 1.5 \\
Thickness of ground dry soil layer (cm) & \multicolumn{7}{c}{ January 5, 2012, 11:10 a.m. } \\
\hline Survey time & 4.8 & 10.7 & 8.7 & 0 & 10.0 & 7.5 \\
\hline Snow thickness (cm) & 85 & 95 & 95 & $<10$ & 80 & 70 \\
Snow coverage (\%) & 0 & 0 & 0 & 6.4 & 1.0 & 2.0 \\
Thickness of ground dry soil layer (cm) & & & & \\
\hline
\end{tabular}


twice on December 14, 2011 and January 5, 2012. The survey showed that, on the slope with the same slope aspect, the thickness of snow on the land remedied with feldspathic sandstone was bigger than that of original sand without remediation, the snow on remedied land melted slowly, and the snow on sunny slope of sand without remediation after snowing for $40 \mathrm{~d}$ was almost totally melted; from the angle of terrain, snow melting speed was sunny slope $>$ plane $>$ shady slope; frozen layer on remedied land appeared from the surface. When the sand was covered with snow, surface layer still had 1-2 cm dry sand layer (Figure 1a). After the snow on sand surface layer was melted, thickness of dry sand layer increased, within $5-8 \mathrm{~cm}$.
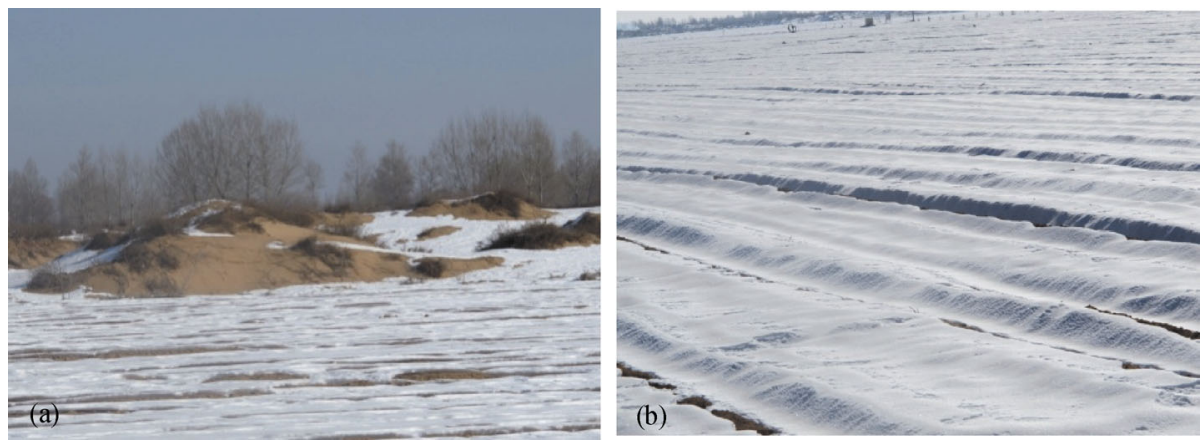

Figure 1 Dry sand layer with snow (a) and mixed land of feldspathic sandstone with snow cover (b)

After land remediation, feldspathic sandstone did not have dry sand layer after being covered, ground surface layer under original sand landform snow had one layer of dry sand layer. Sand soil without remediation had many non-capillary pores with good water transmission performance, and the melted snow water could rapidly infiltrate downward to sand layer; and feldspathic sandstone and fine texture, developed capillary pores, good water preservation, poor water transmission (Han et al., 2012) and high surface moisture content, which would be frozen as temperature drops, and surface layer snow melted slowly. Snow and soil frozen layer formed two protective layers on the surface, reducing the wind erosion effect in the fallow period (Figure 1b).

After land remediation with feldspathic sandstone, soil property and sand microtopography were changed. The following analysis of sand stabilization effect of feldspathic sandstone in the fallow period was made considering these two aspects.

\subsection{Effects of soil properties change on sand stabilization}

After the sand was mixed with feldspathic sandstone, soil character would be changed from sandy soil into silty loam, capillary pore would increase, noncapillary pore would reduce, and water preservation would improve. Improvement of water preservation of soil on sand surface layer and increase of soil moisture content changed molecular force among soil particles and helped the implementation of biological sand stabilization measures, thus improving soil structure and wind erosion resistance of soil.

\subsubsection{Effects of mixed soil moisture change on sand stabilization}

The lack of soil moisture is the biggest stumbling block for vegetation growth; insufficient moisture will cause earlier weakening of vegetation. Feldspathic sandstone itself has the 
effect of natural water retention agent, remedies Mu Us Sandy Land by mixing feldspathic sandstone and sand to improve water preservation effect of soil surface layer of sand and moisture conditions, and enables biological sand stabilization measures to constantly exert effect. Moisture content of sand soil is a very important wind erosion resistance factor. If surface moisture content increases, starting wind speed of sand grain will increase (Liu and

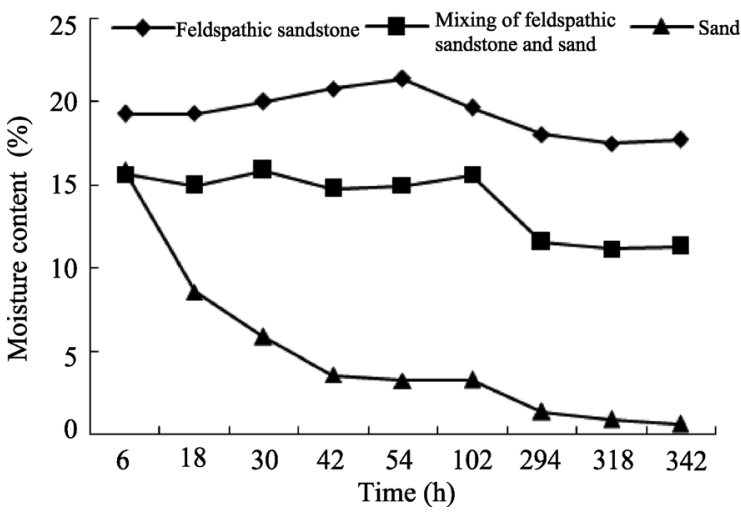

Figure 2 Variation of moisture content as time changes Dong, 2002). When air flow blows over underlying surface consisting of loose particles, sand grain is affected by head resistance and gravity; as far as sand grain with grain size less than $0.1 \mathrm{~mm}$, the effect of cohesion and viscous force should also be considered. When the sand contains moisture, the strain between water molecule and sand grain particle would enable the cohesion among particles to increase, enabling it not easy to be risen. $2 \%$ sand soil moisture content is an important turning point, when moisture content is less than $2 \%$, windblown erosion resistance is poor and change is big; when moisture content is more than $2 \%$, wind erosion resistance tends to be stable; when moisture content reaches saturation capacity, extreme wind speed of wind erosion resistance is stabilized by about $14 \mathrm{~m} / \mathrm{s}$, which can resist Grade 6-7 gale (Dong and Qian, 2007).

After saturating feldspathic sandstone, mixture of feldspathic sandstone with sand and sand, observed $342 \mathrm{~h}$ soil moisture content as time changes (Figure 2), and found that, feldspathic sandstone and mixture of feldspathic sandstone with sand changed little as time goes, respectively $1.59 \%$ and $4.38 \%$; and minimum moisture content was respectively $17.49 \%$ and $11.57 \%$, exceeding sand's saturation moisture content, therefore, it could resist at least $14 \mathrm{~m} / \mathrm{s}$ wind speed erosion. When sand was observed for $294 \mathrm{~h}$, moisture content was $1.39 \%$, lower than $2 \%$; wind erosion resistance became very poor. Therefore, feldspathic sandstone and sand was mixed by increasing moisture content of soil surface layer to improve windblown erosion resistance.

In addition, Mu Us Sandy Land has cold climate and high soil moisture content, which will generate soil frozen layer; if moisture content is low, it will be hard to form frozen layer (Table 2). On the one hand, after the water is frozen, it generates a large quantity of hydrogen bonds, the ice has tetrahedral crystal structure, and hydrogen bonds connect this tetrahedron into as a whole. Under the effect of ice, single-grain sand is cemented into one layer of protective casing to isolate direct connection between air flow and loose sand surface, thus can reduce the wind erosion.

Increase of soil moisture content is good for survival of protection forest. According to the erosion features in project area, the protection forest was placed with "net-shape" to form criss-cross forest protection belt, and supported with sea buckthorn, sand willow and other shrubs to form three-dimensional wind prevention and sand stabilization system. After land remediation, survival rate of protection forest could reach $85 \%$; survival rate of aspen on the sand without remediation was $52 \%-84 \%$ (Tai et al., 2004). Sand remediation with 
feldspathic sandstone provided advantageous conditions for biological sand stabilization.

\subsubsection{Effects of mixed soil stability change on sand stabilization}

Sand stabilization effect of Mu Us Sandy Land after mixing feldspathic sandstone with sand into soil is closely related to the stability of soil structure. Water stable aggregate means that soil structure form will not be broken after soil structure is immersed in the water, water stable aggregate is not only the important component of soil but also the productivity that ensures and coordinates liquid manure and gas heat in the soil, impacts type and activity of soil enzyme, maintains and stabilizes loose curing layer of soil and directly influences plant. Compare mixing proportion of feldspathic sandstone with sand based on 1:1, 1:2 and 1:5, and water stable aggregate quantity in mixed soil before plantation and after one-season and two-season planting (Table 3).

Table 3 Mass percentage (\%) of water stable aggregate of soil mixed with feldspathic sandstone and sand

\begin{tabular}{cccc}
\hline $\begin{array}{c}\text { Feldspathic } \\
\text { sandstone: sand }\end{array}$ & $\begin{array}{c}\text { Before } \\
\text { planting }\end{array}$ & $\begin{array}{c}\text { One-season } \\
\text { planting }\end{array}$ & $\begin{array}{c}\text { Two-season } \\
\text { planting }\end{array}$ \\
\hline $1: 1$ & 28.22 & 29.29 & 29.33 \\
$1: 2$ & 21.55 & 21.87 & 23.92 \\
$1: 5$ & 18.38 & 18.02 & 20.82 \\
$0: 1$ (sand ) & 10.87 & 11.50 & 11.29 \\
\hline
\end{tabular}

With the extension of planting time at different proportions, the quantity of aggregate in mixed soil tended to increase, indicating that soil structure had gradually cured and developed benignly. Compared with total load, if the sand was remedied with feldspathic sandstone, soil aggregate content would increase, and the added values were respectively: $7.51 \%-17.35 \%$, $6.52 \%-17.79 \%$, and $9.53 \%-18.04 \%$. Sand

remediation with feldspathic sandstone was helpful for increasing aggregate content, enhancing soil structure and intensifying the sand stabilization and soil formation effect.

\subsection{Effects of terrain factors change on sand stabilization}

Land remediation engineering changed the sand's terrain conditions of original landform, discrepancy in elevation of sand's original landform was within $10 \mathrm{~m}$, flatness after land remediation was within 5\%-10\%o, and the surfing sand dune was changed into flat ground, changing surface energy distribution and impacting the strength of wind erosion as well.

Sand dune was divided into sunny slope, shady slope, semi-sunny slope and semi-shady slope, the remedied land was flat without obvious slope aspect. According to the research (Fuh Bawpuh, 1958), radiating seasonal gross and annual gross of slopes at different slope aspects was different as latitude and gradient changed, and the variation trend was different as well. Especially in winter half year, radiating gross on south slope was much more than that of flat ground, and the higher the latitude was, the bigger gradient would be (but not more than the hottest gradient) and the bigger difference between them would be. For example, on the south slope with the hottest gradient $\left(67^{\circ}\right)$ at latitude 50 , solar radiation gross in winter could reach $79.9 \mathrm{kcal} / \mathrm{cm}^{2}$, and solar radiation gross on flat ground in the same period was $80.2 \mathrm{kcal} / \mathrm{cm}^{2}$, both ones were nearly equal. In winter and the entire year, when the radiation on horizontal plane rapidly decreased as latitude increases, but solar radiation gross of radiation area on south slope with big gradient increased as latitude rose. Therefore, sunny slope received bigger solar radiation and had faster snow melting speed. After land remediation, solar energy distribution in the sand changed, latitude of Mu Us Sandy Land 
was within $37^{\circ} 27^{\prime}-39^{\circ} 22^{\prime} \mathrm{N}$, sun incidence angle in winter was small and snow melted slowly.

Wind is the driving force of windblown sand movement, the process of surface sand grain divorced from earth's surface under wind field effect and initial motion has become the start of sand grain, which marks the beginning of surface wind erosion. Under certain condition of wind direction, wind speed has always played a decisive part in the whole motion process of sand grain. Protection forest in project area effectively reduced wind speed (Bao et al., 2007). Compared with plane under this condition, when wind direction is fixed, windblown sand on slope is more easily raised (Wu et al., 2010). Windblown sand movement of the exposed cultivated land is different from windblown sand movement of desert, sand rising wind speed of cultivate land is faster than that of desert sand (Shen and Zou, 2005). After land remediation, ground gradient diminished, thus increasing wind speed of sand rising and strengthening wind erosion resistance of soil.

\section{Conclusion}

Land remediation for Mu Us Sandy Land with feldspathic sandstone changed soil conditions and terrain conditions of land remediation region and reduced windblown sand level of project area, especially feldspathic sandstone still has the sand-fixation function in the fallow period.

Feldspathic sandstone has water preservation effect that can expand sand soil moisture loss, increase soil moisture content, speed up sand rising wind, and enhance the soil's corrosion resistance. Due to high soil moisture content, earth's surface will tend to form frozen layer and snow coverage is big, reaching more than $85 \%$. With the increase of cohesion, two protective layers of snow cover and soil frozen layer have been formed to reduce wind erosion effect.

In addition, soil moisture loss slowed down and moisture content increased by over 3 times. Condition improvement was helpful for promoting the implementation effect of the biological sand stabilization measures, increasing survival rate of protection forest to $85 \%$ and effectively reducing wind speed, thus mitigating wind erosion. Third, remediation of soil of $\mathrm{Mu}$ Us Sandy Land improved stability of soil structure through crop planting and increase of soil water stable aggregate content and provided advantageous conditions for sand stabilization effect of feldspathic sandstone. After land remediation, land flatness was improved and terrain factor of slope surface erosion was moderated.

Land remediation for $\mathrm{Mu}$ Us Sandy Land with feldspathic sandstone under the common effects of climate, soil and microtopography conditions resulted in low wind erosion effect in the fallow period.

\section{References}

Bao Yuhai, He Xiubin, Yang Jihua et al., 2007. Study on preventing effect of three farmland shelter-forest network on soil wind erosion. Journal of Soil and Water Conservation, 21(2): 5-8. (in Chinese)

Dong Zhibao, Qian Guangqiang, 2007. A review on effect of soil moisture on wind erosion threshold velocity. Acta Pedologica Sinica, 44(5): 934-942. (in Chinese)

Fuh Bawpuh, 1958. The influence of slope on the sunniness. Journal of Nanjing University (Natural Sciences), (2): $23-46$. 
Han Jichang, Xie Jiancang, Zhang Yang, 2012. Potential role of feldspathic sandstone as a natural water retaining agent in Mu Us Sandy land, northwest China. Chinese Geographical Science, 22 (5): 550-555.

Han Jichang, Zhang Yang, 2014. Land policy and land engineering. Land Use Policy, 40: 64-68.

Jiang Deming, Cao Chengyou, Toshio Oshida et al., 2008. Study on the effects of protection against wind, sand-fixation and soil improvement of Caragana microphylla plantations in Horqin sand land. Arid Zone Research, 25(5): 653-658. (in Chinese)

Kong Dezhen, 1996. The ecological economic principle for comprehensive development and management of Maowusu sandland. Pratacultural Science, 13(3): 13-15. (in Chinese)

Liu Xiaoping, Dong Zhibao, 2002. Wind threshold shear velocities of sands at moistened state. Bulletin of Soil and Water Conservation, 22(2): 1-4, 61. (in Chinese)

Liu Yansui, Fang Fang, Li Yuheng, 2014. Key issues of land use in China and implications for policy making. Land Use Policy, 40: 6-12.

Liu Yansui, Yang Ren, Li Yuheng, 2013. Potential of land consolidation of hollowed villages under different urbanization scenarios in China. Journal of Geographical Sciences, 23(3): 503-512.

Liu Yansui, Zhang Yanyu, Guo Liying, 2010. Towards realistic assessment of cultivated land quality in an ecologically fragile environment: A satellite imagery-based approach. Applied Geography, 30(2): 271-281.

Shen Xiangdong, Zou Chunxia, 2005. Characteristic of wind-sand movement on bare tillage. Journal of Agro-environmental Science, 24(5): 909-912. (in Chinese)

Tai Xianwu, Wu Jingyun, Zhang Xiuyan et al., 2004. Experiment of poplar shelterbelt-forest afforestation sandy land. Protection Forest Science and Technology, 3: 13-14. (in Chinese)

Wang Yuanchang, Wu Yonghong, Kou Quan, 2007. Definition of arsenic rock zone borderline and its classification. Science of Soil and Water Conservation, 5(1): 14-18. (in Chinese)

Wu Jianjun, Sun Huanqing, He Lihong, 2010. Factors influencing threshold wind velocity of sand particles. Journal of Desert Research, 30(4): 743-748. (in Chinese)

Yan F, Wu B, Wang Y J, 2013. Estimating aboveground biomass in Mu Us Sandy Land using Landsat spectral derived vegetation indices over the past 30 years. Journal of Arid Land, 5(4): 521-530.

Ye Hao, Shi Jiansheng, Wang Guiling, 2006. Effect of chemical compositions of Pisha sandstone on the gravity erosion. Hydrogeology \& Engineering Geology, 6: 5-8. (in Chinese) 